Anne Lise Laursen*

\title{
Plain Language - a Panacea of Linguistic Quality Assurance?
}

\begin{abstract}
This article questions the use of a set of principles or guidelines, often referred to as language policies or language guides, which proliferate in companies and organisations as a means of harmonizing and modernizing corporate discourse. The language guide recommendations promote certain syntactic and lexical features which seem to have been inspired by the plain language campaigns conducted in various countries with the purpose of setting up a framework for a simplification of the public-sector discourse from administration to citizens. The problem of applying theses principles as an overall instrument of assuring the linguistic quality of private companies has been pointed out on various occasions. However, the argumentation has until now been made on an impressionistic or introspective basis. The article demonstrates that the inventory of linguistics in fact offers a range of possibilities to give a theoretical and empirical support to the arguments. Based on a set of language guide recommendations from Danish companies, it is illustrated how variations in discourse elements, i.e. purpose, domain and audience, conventionally call for variations in the linguistic devices used. In other words, from a discoursal point of view, the set of plain language-like recommendations for paradigmatic stylistic choices cannot be expected to cover every instance of business communication. Furthermore, it is argued that certain intralingual and interlingual features require empirical research in order to establish a stylistically adequate framework of this instrument of language management in companies.
\end{abstract}

\section{Introduction}

The language policies or language guides introduced in Danish companies in recent years might be seen as a consequence of changes in the contextual circumstances (Grundfos 2004). The accelerating globalisation has been accompanied by linguistic challenges for the company

\footnotetext{
* Anne Lise Laursen

Aarhus School of Business, Aarhus University

Dept. of Language and Business Communication; Teaching Group Spanish

Fuglesangs Allé 4

DK-8210 Aarhus V

all@asb.dk
}

Hermes - Journal of Language and Communication Studies no 43-2009 
staff, and the growing impact of e-mail communication in many cases means skipping the intermediate stage of corporate language experts. This has led to a situation where the group of senders have become heterogeneous in terms of language competences, and this subsequently implies a communication code of varying quality (Laursen 2005: 1). Looking for guidelines to deal with this inconsistency of language use, the company staff in many cases seem to have resorted to already existing principles in the international plain language campaigns. These campaigns were launched with the communication of the public sector in mind. The adoption of the principles by private companies is, however, likely to cause some mismatch between means and intentions. From a discoursal point of view, it has to be underlined that the discourse environment that gave birth to the plain language principles in the first place is completely different from the environment where these principles are being adopted.

For one thing, the actors of the discourse community related to the genres of public information that the plain language principles originally were meant for, are civil servants and citizens - a heterogenic community consisting of a group of experts and a group of laymen of unequal background. On the contrary, the prototypical private sector actors are producers and clients or sellers and buyers - a discourse community which could be expected to share or at least be close to each other in terms of reaching an agreement of the rationale of the discourse and therefore less likely to encounter misunderstandings.

Secondly, the goal of introducing the plain language principles in the public sector was to get away from an archaic discourse pattern, which made the discourse extremely opaque, heading towards a modern and transparent discourse. On the contrary, the alleged goal of the companies has been to introduce an instrument of linguistic quality assurance.

Thirdly, the prototypical purpose of the discourse of the public sector is to inform about decisions made by the authorities in order to make people react (pay taxes, for example) or in order to ban or admit the act of something (for a more in-depth description of public sector communication, see Rehbein 1998: 663-664), while buying-selling negotiation can be said to constitute the 'umbrella' of purposes of the business discourse (Akar/Louhiala-Salminen 1999: 212-213). 
In the following sections, I will focus on some problematic aspects of using plain language principles in business communication. In section 2, I will briefly describe the raison d'être and development of the plain language concept and its relevance for the public sector. In section 3, I shall discuss the Danish business approach of language policies and on the basis of examples from instances of business communication I shall point out specific problems related to the individual features of the plan language principles. In section 4, I shall discuss certain cross-linguistic problems involved. In these sections (3 and 4), I will exemplify how theoretically and empirically based arguments can contribute to bringing nuances to the part of the corporate language guidelines which sets the framework for the use of specific syntactic and lexical elements in business communication. Following Bergenholtz/Johnsen (2006: 198), I will use the term 'style selecting policies', and 'style selecting guidelines' to describe the recommendations concerning the paradigmatic choices included in these corporate language policies. My description will be situated within the framework of genre analysis, understanding genres as defined by Swales (1990: 58), as a function of the variables of communicative purpose, discourse community and thereby the underlying rationale of the discourse, which again influences or constrains the choice of form, for instance the stylistic choices. I will draw upon different linguistic disciplines to support the argumentation.

\section{Plain language}

The plain language movement set out in 1979 in the UK with the Plain English campaign and since then it has been crusading against "gobbledygook, jargon and misleading information" in the public sector (see further discussion at http://www.plainenglish.co.uk/).

This first initiative has been followed by an increasing plain language movement in English speaking countries, especially the USA, Canada and Australia. It has later gained momentum in e.g. Sweden and France. According to the Plain Language Association International (cf. http://www.plainlanguagenetwork.org/), the stakeholders of the movement are now both governments and specific sector segments, e.g. within the legal and medical professions. The European Union has joined the movement with the Fight the Fog campaign launched in 1998 by the European Commission's Translation Service to encourage authors and 
translators to write more clearly with the general public in mind (European Commission Translation Service 1998).

In Denmark, the booklet Og uden omsvøb, tak! ('Plain language, please!'), published by the Danish State Information Service (Møller/ Hansen 1981) for the public sector staff, arose from a wish to combat the public sector's preference for bureaucratic style in their communication to the citizens. The Danish 'gobbledygook' was characterised by the use of highly hierarchical sentence structures, heavily pre-modified noun phrases and the use of a - for the average citizen - rare vocabulary. So, there was indeed a profound need for a change of register. The booklet of 1981 focused on the following stylistic elements:

short words

$>$ common words

$>$ sentence limit: $22-25$ words

$>$ average limit: 15 -18 words

$>$ no pre-modifiers

Table 1: Elements of the first edition of style selecting guidelines from the Danish public sector

Since then, most public information has been stylistically modernised, but the crusade for simplification continues. The style selecting policies of a number of public institutions accessible at the site of the Danish National IT and Telecom Agency (IT- og Telestyrelsen) inevitably contains the following 'do's and don'ts':

\begin{tabular}{|l|l|}
\hline$>$ Use: & $>$ Avoid: \\
- verbs instead of & - passive voice \\
nouns & $\&$ \\
- short sentences & impersonal style \\
$(15-20$ words on & \\
average $)$ & \\
\hline
\end{tabular}

Table 2: Recent trends in style selecting guidelines in the Danish public sector 


\section{Language policies - the Danish company version}

The concept of language policies can be defined as a regulation of language issues, either between languages, the interlingual language policies, or within one particular language, the intralingual language policies (cf. Bergenholtz/Tarp 2005: 4). It is common knowledge that the issue of an interlingual language policy, in the case of coexistence of two or more languages in a community, is to protect or support one particular language, or to equalise the national languages in question. Also the intralingual policies are known to have elements of protecting or supporting certain aspects of the individual language, for instance by protecting against foreign loan words and by encouraging the use of replacement words in the national language.

The Danish company version focuses exclusively on intralingual issues encouraging specific stylistic choices of language use.

So far, in spite of the linguistic challenges in companies and the accelerating need for communicating in L2, no interlingual version of style selecting policies has yet been introduced.

\subsection{Plain language principles in a new discourse community}

The Danish companies' style selecting policies contain the overall guidelines of written communication for the staff as such.

The following comparison of the predominant linguistic elements of the guidelines in five Danish companies reflects a striking similarity between the individual guidelines and at the same time it shows loyalty to the plain language principles of the public sector.

\begin{tabular}{|l|l|l|l|l|l|}
\hline & $\begin{array}{l}\text { Prod. } \\
\text { sector }\end{array}$ & $\begin{array}{l}\text { Prod. } \\
\text { sector }\end{array}$ & $\begin{array}{l}\text { Prod. } \\
\text { sector }\end{array}$ & $\begin{array}{l}\text { Financial } \\
\text { sector }\end{array}$ & $\begin{array}{l}\text { Insurance } \\
\text { company }\end{array}$ \\
\hline Short sentences & $\begin{array}{l}15-20 \\
\text { w./sent. }\end{array}$ & + & $\begin{array}{l}15-18 \\
\text { w./sent. }\end{array}$ & $\begin{array}{l}20-25 \\
\text { w./sent. }\end{array}$ & + \\
\hline Active voice & + & + & + & + & + \\
\hline $\begin{array}{l}\text { Verbs - not } \\
\text { nouns/nomina- } \\
\text { lisations }\end{array}$ & + & + & + & + & - \\
\hline
\end{tabular}

Table 3: Style selecting elements in the language guidelines of five Danish companies (cf. Laursen 2005) 
As mentioned above, however, the discourse variables related to private companies are fundamentally different from those of the public sector. The discourse community of business communication is dominated by individuals whose main work activities and interests are in the domain of business and who come together for the purpose of doing business (Bargiela-Chiappini/Nickerson 1999: 2), and, as it has already been commented upon in section 1 , the stylistic requirements as to the level of register is not understandability but quality. Finally, the genres within business communication have inherent features that to a certain extent constrain the plain language recommendations within the parameters of voice, vocabulary and sentence length. The following points will support the claim for a differentiation.

\subsection{Voice, vocabulary and sentence length in business discourse}

According to Brünner (2000: 17), business communication can be related to two domains, i.e. technical issues concerning the product that constitutes the basis of the buying-selling negotiation, and economic issues concerning the profit-making aspects, i.e. the results of the buyingselling negotiation, of the company. Both domains are characterised by specialised registers that include certain paradigmatic choices within at least two of the plain language parameters considered, namely voice and vocabulary.

The use of active voice and the use of verbs instead of nouns have been commented upon previously as being specifically inadequate when it comes to specialised texts, which are largely characterised by both passive voice and a nominal style, (Bergenholtz et al. 2003: 156). Apart from these general observations, a number of specific arguments can be added in this context.

Let us take an example from the economic domain - an extract of the explanatory notes of a recent Carlsberg Annual Report (Carlsberg 2006): 
(1)

Depreciation is calculated on the basis of the residual value less impairment. The residual value is determined at the date of acquisition and reassessed annually. If the residual value exceeds the carrying amount, depreciation is discontinued.

(Emphasis added)

Using the inventory of the Prague school theory of the functional sentence perspective, the prototypical information structure of specialised texts is that the products, processes, results etc. dealt with constitute the theme or topic of the propositions and thereby under normal circumstances are materialised as the sentence subject. This calls for the use of the passive voice. Furthermore, using the inventory of the Fillmore case-grammar, this construction permits the writer to suppress the agent of the proposition - a semantic role which is irrelevant in many genres of specialised texts. In the above Carlsberg example it would be of no relevance for the reader to be introduced to the agent - in casu the auditor or the book keeper - who has been taking care of these accounting manoeuvres of calculating depreciations, determining the residual value, etc.

The preference for nouns in specialised texts can be explained by the same effect, namely the fact that the use of this device entails suppression of the agent of the underlying proposition as well. Furthermore, nouns, including nominalisations, for instance depreciation in the above example, are typically preferred to verbs as being bearers of the essential characteristics of the specific concepts in the LSP texts. This feature is testified by the working methods of terminology and LSP lexicography, where the selection of terms or lemmata shows the protagonism of nouns.

In the technical domain, nouns or nominalisations are particularly frequent: They are denominations of the company's products and otherwise permit precise descriptions of the processes. This can be exemplified by the following extract from a consumer-oriented data sheet of a Danfoss radiator thermostat: 
(2)

The electronic box of the thermostat is easy to remove, thereby allowing access to function buttons and LCD display for clear and convenient checks or modifications to programs and heating periods

(Emphasis added)

The application of plain language principles on the above LSP-domains would be constrained not by the language system per se, but by the conventions of these genres focusing on relevancy and precision under the purposive umbrella of 'doing business' - maybe even with the underlying purpose of 'presenting the company as a qualified partner', originally linked to company brochures (cf. Askehave/Swales 2001: 204), but which might prove to cover a range of genres within the economic and technical domains, respectively.

As to the sentence length, there is no linguistic or discoursal evidence for general genre-imposed constraints on using the plain language principles of short sentences. However, as indicated by Bhatia (1993: 107) simplification as such might promote ambiguity and lack of clarity. The following quotation from one of the Danish language guides showing the examples of the do's and don'ts of the sentence length parameter, could be an instance of this argument:

(3)

\begin{tabular}{|l|l|}
\hline Write like this: & Don't write like this: \\
\hline $\begin{array}{l}\text { In order to dismantle the } \\
\text { motor, firstly it might be }\end{array}$ & $\begin{array}{l}\text { In order to dismantle the } \\
\text { motor, at first it might } \\
\text { necessary to remove a } \\
\text { be necessary to remove } \\
\text { possible yawing device. } \\
\text { a possible yawing device } \\
\text { necondly, it might be } \\
\text { necessary to dissemble } \\
\text { ands dissemble parts of } \\
\text { the motor in order to be } \\
\text { to be able to disconnect it } \\
\text { from the gear. }\end{array}$ \\
able to disconnect it \\
from the gear.
\end{tabular}

(My translation)

As can be observed in example 3, no matter which sentence represents the original propositional content, the two sentences are not equivalent. If the intention has been to demonstrate how to split up one sentence 
into two, this might be an instance of trade-off between simplification and precision.

In general, tailoring the sentence length norms to fit the genre specific conventions could call for empirical studies across genres. Not as a means of identification of the genre, but as a means of putting the sentence length parameter of the company's style selecting guidelines into perspective.

\section{Cross-linguistic constraints}

The issue of cross-linguistic factors is of paramount importance when you look at the materialisation of business communication in a foreign language. Even if the rationale of the community is the same in an extralinguistic perspective, the linguistic conventions might be different. As an example, I shall try to illustrate the problems of applying the plain language principles when it comes to translation of business material into Spanish.

The contrastive features between members of the Germanic and Romance families have been intuitively recognised by anyone dedicated to translations between any language pair belonging to these two language families, and isolated examples have been highlighted to encourage for instance syntactic shifts as a translation strategy. However, both theoretical and empirical studies can now give more substantial evidence for the contrastive elements of language use. I shall look at these possibilities in the following subsections.

\subsection{Evidence for contrastiveness}

In the introduction to their monumental work from 1958, Vinay \& Darbelnet pointed out that their comparison of French and English had permitted them "to isolate characteristic features of French, and by contrast also features of English, which would remain hidden to the linguist working with a single language”(Vinay/Darbelnet 1995: 9). The seven methods of translation developed by them is an (implicit) evidence for the existence of certain contrastive features between the specific language pair rather than a taxonomy of contrasts. One type of contrastive feature, however, can be generalised, namely the predominance of 
French nouns compared to English, which can be observed at different structural levels:

(4)

to review: passer en revue

people cheered as the troops marched by: les gens ont applaudi sur le passage des troupes

(Vinay/Darbelnet 1995: 99)

Recently, a group of scholars at the Copenhagen Business School have set up a theoretical framework within which the contrastive features of the Germanic and Romance languages can be described (Korzen/Lundquist 2003). Their study focuses especially on the contrasts between the Scandinavian and Romance languages: the endocentric (Scandinavian) family, characterised by relatively more information weight in the centre of the proposition, i.e. the verb, and the exocentric (Romance) family, characterised by relatively more information weight outside the verb/verbal phrase, i.e. in the noun. This involves two important stylistic differences, namely the predominance of nominal style and hypotaxis in the exocentric languages and, by contrast, the predominance of verbal style and parataxis in the endocentric languages.

According to the Copenhagen scholars, the nominal style is supported by infinite verbal forms with the subsequent loss of more or less verb-inherent features or, in other words, the nominal style is characterised by less finite verbs than is the case of the verbal style. Korzen (2005) quantifies this specific structural difference on the basis of empirical studies of a Danish-Italian parallel text corpus. It corroborates the higher tendency of deverbalisation in Italian compared to Danish: The propositions textualised without a finite verb amount to $12,04 \%$ in Danish texts and 47,11\% in Italian texts (Korzen 2005: 29).

\subsection{Evidence from the language pair of Danish and Spanish}

The comparison in example 5 of two parallel texts consisting of the auditors' report from a Danish and a Spanish annual report supports the above observations of Korzen et al. It indicates that the contrastive features of Romance languages compared to e.g. Danish - observed in the Danish-Italian corpus - indeed apply to Spanish, too. The texts are 
identical in terms of content while the surface structures illustrate the typological differences of language use:

(5)

\begin{tabular}{|c|c|}
\hline $\begin{array}{l}\text { Til aktionærerne i IC Companys } \\
\text { A/S } \\
\text { Vi har revideret årsrapporten for } \\
\text { IC Companys A/S for } \\
\text { regnskabsåret } 1 \text {. juli } 2004 \text { - } 30 . \\
\text { juni 2005, der aflægges efter } \\
\text { årsregnskabsloven og } \\
\text { Københavns Fondsbørs krav til } \\
\text { regnskabsaflæggelse.// Selskabets } \\
\text { ledelse har ansvaret for } \\
\text { årsrapporten.// Vort ansvar er på } \\
\text { grundlag af vor revision at afgive } \\
\text { en konklusion om årsrapporten.// } \\
\text { Den udførte revision } \\
\text { Vi har udført vor revision i } \\
\text { overensstemmelse med danske } \\
\text { revisionsstandarder.// Disse } \\
\text { standarder kræver, at vi } \\
\text { tilrettelægger og udfører } \\
\text { revisionen med henblik på at opnå } \\
\text { høj grad af sikkerhed for, at } \\
\text { årsrapporten ikke indeholder } \\
\text { væsentlig } \\
\text { fejlinformation.//Revisionen } \\
\text { omfatter stikprøvevis } \\
\text { undersøgelse af information, der } \\
\text { understøtter de i årsrapporten } \\
\text { anførte beløb og } \\
\text { oplysninger.//Revisionen } \\
\text { omfatter endvidere stillingtagen } \\
\text { til den af ledelsen anvendte } \\
\text { regnskabspraksis og til de } \\
\text { væsentlige skøn, som ledelsen har } \\
\text { udøvet, samt vurdering af den } \\
\text { samlede præsentation af } \\
\text { årsrapporten.// }\end{array}$ & $\begin{array}{l}\text { A los accionistas de Industria de } \\
\text { Diseño Textil S.A. } \\
\text { Hemos auditado las cuentas } \\
\text { anuales consolidadas de Industria } \\
\text { de Diseño Textil, S.A. (la } \\
\text { Sociedad) y sociedades } \\
\text { dependientes (el Grupo) que } \\
\text { comprenden el balance de } \\
\text { situación consolidado al } 31 \text { de } \\
\text { enero de } 2006 \text { y la cuenta de } \\
\text { pérdidas y ganancias consolidada, } \\
\text { el estado consolidado de flujos de } \\
\text { efectivo, el estado consolidado de } \\
\text { cambios en el patrimonio neto y la } \\
\text { memoria de las cuentas anuales } \\
\text { consolidadas correspondientes al } \\
\text { ejercicio anual terminado en dicha } \\
\text { fecha, cuya formulación es } \\
\text { responsabilidad de los } \\
\text { administradores de la sociedad. } \\
\text { //Nuestra responsabilidad es } \\
\text { expresar una opinión sobre las } \\
\text { citadas cuentas anuales } \\
\text { consolidadas en su conjunto, } \\
\text { basada en el trabajo realizado de } \\
\text { acuerdo con normas de auditoría } \\
\text { generalmente aceptadas en España, } \\
\text { que requieren el examen, mediante } \\
\text { la realización de pruebas selectivas, } \\
\text { de la evidencia justificativa de las } \\
\text { cuentas anuales consolidadas y la } \\
\text { evaluación de su presentación de } \\
\text { los principios contables aplicados y } \\
\text { de las estimaciones realizadas.// }\end{array}$ \\
\hline $\begin{array}{l}\text { Additions:// = full stop } \\
\text { Bold = finite verbs }\end{array}$ & $\begin{array}{l}\text { Additions:// = full stop } \\
\text { Bold = finite verbs }\end{array}$ \\
\hline $\begin{array}{l}\text { No. of words: } 127 \\
\text { No. of sentences/periods: } 7 \\
\text { No. of finite verbs: } 13\end{array}$ & $\begin{array}{l}\text { No. of words: } 157 \\
\text { No. of sentences/periods: } 2 \\
\text { No. of finite verbs: } 5\end{array}$ \\
\hline
\end{tabular}

On the basis of approximately the same number of words (the difference being mainly due to the Spanish explicitation of the different parts of the annual report - balance sheet, etc.), the comparison gives a clear picture of the structural differences in terms of hypotaxis vs. parataxis, i.e. subordinated sentences and infinite verbs vs. coordinated sentences and finite verbs. 


\subsection{Comparison of text structure via Lix index}

As indicated by Cristelle Cosme (2006: 2), contrastive studies have over the past few decades been favoured by the availability of authentic texts stored in electronic form and consequently contrastivists are now able to base their cross-linguistic claims on authentic language use rather than on slim empirical foundation or even mere introspection. In order to quantify some of the observations of contrastiveness between Danish and Spanish, I used a Lix index-program to process a small text corpus.

Lix is a readability index developed by the Swedish scholar Björnsson (1983), which combines the length of the sentence with the percentage of long words, ranging from scores of $55<$ (very difficult, e.g. academic texts and law texts) to 24> (easy for all readers, children's literature). Studies made by Courtis (1995) and Courtis/Hassan (2002) have proved the Lix formula to be an operational instrument of measuring readability in non-Scandinavian languages on equal footing with other international readability indicators, like for instance the Flesch, Fog or Rix indexes including a cross-linguistic approach in the "first bilingual readability study reporting on different language versions on corporate annual reports” (Courtis/Hassan 2002: 394).

Apart from being a measure of the readability of individual texts, however, the Lix formula - being dependent on the length of sentences and words - can be used as a quick diagnostic means for discovering structural differences in texts, and as such, contribute to detecting stylistic differences between different languages when applied to sets of texts which are more or less identical in terms of content.

The application of the Lix index made by Laursen (2005) on a set of auditors' reports characterised by being relatively invariable as to content showed a remarkable regularity of contrasts between the language pair compared: 


\begin{tabular}{|l|c|l|c|}
\hline Company (DK) & Lix scores & Company (E) & Lix scores \\
\hline A.P. Moeller & 62 & Amper & 81 \\
\hline Carlsberg & 51 & Arcelor & 81 \\
\hline Coloplast & 54 & Sniace & 78 \\
\hline Danisco & 50 & Recoletos & 81 \\
\hline ISS & 54 & Grupo Sehrs & 80 \\
\hline
\end{tabular}

Table 5. Lix scores in auditors' reports (Laursen 2005)

As can be seen, the tendency of scores for each language pointed at two different zones, the Danish circulating around 55 and the Spanish around 80 . The scores in each group indicate, however, a certain stereotype pattern of this sub-genre.

A corresponding study of another section of the annual report - here including word count - provides a picture that is similar to that of the auditors' report. Table 6 shows the result, based - according to the Lix routine - on a selection of 200 words from the first, middle, and final section of each of the management's reviews:

\begin{tabular}{|l|c|c|c|c|l|l|l|l|c|}
\hline $\begin{array}{l}\text { Company } \\
\text { (DK) }\end{array}$ & $\begin{array}{l}\text { Ave- } \\
\text { rage } \\
\text { Lix }\end{array}$ & $\begin{array}{l}\text { No. } \\
\text { of } \\
\text { wds. }\end{array}$ & $\begin{array}{l}\text { Long } \\
\text { wds. } \\
\text { \% }\end{array}$ & $\begin{array}{l}\text { Wds/ } \\
\text { sent. }\end{array}$ & $\begin{array}{l}\text { Company } \\
\text { (E) }\end{array}$ & $\begin{array}{l}\text { Ave- } \\
\text { rage } \\
\text { Lix }\end{array}$ & $\begin{array}{l}\text { No. } \\
\text { of } \\
\text { wds. }\end{array}$ & $\begin{array}{l}\text { Long } \\
\text { wds. } \\
\%\end{array}$ & $\begin{array}{l}\text { Wds/ } \\
\text { sent. }\end{array}$ \\
\hline Vestas & $\mathbf{4 7}$ & 636 & $29 \%$ & 18 & Gamesa & $\mathbf{7 1}$ & 653 & $37 \%$ & 34 \\
\hline Carlsberg & $\mathbf{5 7}$ & 635 & $37 \%$ & 20 & Cintra & $\mathbf{6 3}$ & 638 & $29 \%$ & 34 \\
\hline $\begin{array}{l}\text { IC } \\
\text { Companys }\end{array}$ & $\mathbf{5 5}$ & 639 & $39 \%$ & 16 & Inditex & $\mathbf{6 7}$ & 660 & $37 \%$ & 30 \\
\hline B\&O & $\mathbf{5 7}$ & 633 & $34 \%$ & 22 & Abertis & $\mathbf{8 0}$ & 649 & $37 \%$ & 43 \\
\hline FLS & $\mathbf{5 0}$ & 646 & $28 \%$ & 22 & Ferrovial & $\mathbf{6 0}$ & 665 & $28 \%$ & 32 \\
\hline
\end{tabular}

Table 6. Lix scores of management's reviews

The Lix score differences are not quite as spectacular as those of table 5. It appears that the largest gap between the two sets of data can be found in the sentence length whereas the distributional data of the word length show no pattern or regularity.

It should be noted that the percentage of long words may be influenced by some typological differences of the language systems of the 
two languages, e.g. the inflectional system, where the Danish definiteness is marked by a suffix whereas the Spanish is marked by a free morpheme, cf. the Danish udgift > udgiften ('expense' > the expense') versus the Spanish gasto $>$ el gasto. Whether the distributional similarity between the two languages as to the percentage of long words in the range of $28 \%-39 \%$ is due to characteristics of the language system or similarities as to the preference in this genre of annual reports for a particular kind of nouns for instance nominalisations needs to be clarified empirically.

Generally speaking, the above 'slim' demonstration of stylistic differences, of course, does not qualify for any solution as to the recommendations of a possible interlingual version of the company's style selecting guidelines. For one part, it has to be remembered that these features represent an overall difference of language use between the language families, which has nothing to do with individual genres. Nevertheless, the further empirical studies which this demonstration might encourage could focus on concrete genre-related cross-stylistic differences in order to give a qualified back up to this specific feature of the company's style selecting guidelines.

\section{Conclusion}

The above observations concerning the attempt to set up plain language principles in corporate language guides as a means of quality assurance indicate that, in general, the higher level of the existing register of the economic and technical communication in business discourse does not interfere with the interests of the discourse community in question or their purpose of doing business. When it comes to voice and vocabulary, the idiosyncrasy of the corresponding LSP domains in fact constrains the use of plain language. When it comes to sentence length, it might be convenient to turn to empirical studies - not as a facile means of classification of genres (cf. Swales 1990: 46), but as an instrument of tailoring the stylistic recommendations of this feature to fit the already existing genres within business communication. Also, the signs of cross-linguistic differences demonstrated in this article call for contrastive empirical studies in order to be able to offer a qualified alternative to the plain language principles. 
In short, corporate language policies should take into consideration discourse community and purpose as well as register and language type when making recommendations as to stylistic choices of business communication, and in this context some of the stylistic recommendations need to be backed up by further empirical research.

\section{References}

Akar, D./Louhiala-Salminen 1999: Towards a new genre: a comparative study of faxes. In Bargiela-Chiappini, F./Nickerson, C. (eds.), Writing Business: Genres, Media and Discourses. Harlow: Longman, 207-226.

Askehave, I./Swales, J. M. 2001: Genre Identification and Communicative Purpose: A Problem and a Possible Solution. In Applied Linguistics 22/2, 195-212.

Bargiela-Chiappini, F./Nickerson, C. 1999: Business writing as a social action. In Bargiela-Chiappini, F./Nickerson, C. (eds.), Writing Business. Genres, Media and Discourses. Harlow: Longman, 1-32.

Bhatia, V. K. 1993: Analysing Genre: Language Use in Professional Settings. London. Longman.

Bergenholtz, Henning/Johnsen, Mia 2006: Language Policy and Communication Policy - Same Same but Different. In Hermes 37, 95-114.

Bergenholtz, Henning/Tarp, Sven 2005: Política lingüística: Conceptos y Definiciones [online]. http://www.cttic.org/ACTI/Henning_Bergenholtz_y_Sven_Tarp_Politicalinguistica.pdf

Bergenholtz, Henning/Bisgaard, Jonna/Brunsborg, Majken/ Kvist Kwichmann, Kamilla 2003: Sprogpolitik: So ein Ding müssen wir auch haben. In Hermes 31, 135-165.

Björnsson, C.H. 1983: Readability of Newspapers in 11 Languages. In Reading Research Quarterly, Vol. 18, 480-497.

Brünner, G. 2000: Wirtschaftskommunikation. Linguistische Analyse ihrer mündtlichen Formen. Tübingen: Niemeyer.

Carlsberg Annual Report 2006 [online]. http://www.carlsberggroup.com/Investor/ DownloadCentre/Pages/AnnualReport2006.aspx

Cosme, Christelle 2006: Clause combining across languages: A corpus-based study of English-French translation shifts. In Languages in Contrast, Volume 6, Number 1, 71-108.

Courtis, J. K. 1995: Readability of annual reports: Western versus Asian evidence. In Accounting, Auditing \& Accountability Journal, Volume 8, Number 2, 4-17

Courtis, J. K./Hassan 2002: Reading Ease of Bilingual Annual Reports. In Journal of Business Communication 2002, volume 39, 394-413.

Danfoss: Data sheet of Radiator Thermostat [online]. http://heating.consumers.danfoss.com/PCMPDF/VD53P202_RA-Plus.pdf 
European Commission Translation Service 1998: Fight the Fog - Write Clearly [online]. http://ec.europa.eu/translation/writing/clear_writing/fight_the_fog_en.pdf

Grundfos 2004: In other words. Grundfos language guide.

Korzen, I. 2005: Endocentric and Exocentric Languages in Translation. In Perspectives: Studies in Translatology, Vol. 13, No. 1. University of Copenhagen.

Korzen, Iørn/Lundkvist, Lita 2003: Sprogtypologi og overscettelse: Endocentriske og exocentriske sprog. Samfundslitteratur.

Laursen, A. 2005: Towards a corporate language policy [online]. http://www.cttic.org/ ACTI/2004/papers/Anne_Lise_Laursen_Towardsacorporatelanguagepolicy.pdf

Møller, Bent/Hansen, Erik 1981: Og uden omsvøb, tak! Statens Information.

National IT and Telecom Agency (IT- og Telestyrelsen): Sprogpolitik [online]. http:// www.itst.dk/search?SearchableText=sprogpolitik\&x=33\&y=14

Rehbein, J. 1998: Die Verwendung von Institutionensprache in Ämtern und Behörden. In Hoffmann, L./Kalverkämper, H./Wiegand H.E. (Hg.), Fachsprachen: Ein internationales Handbuch zur Fremdsprachenforschung und Terminologiewissenschaft. Berlin/New York: de Gruyter, 660-675.

Vinay, Jean-Paul/Darbelnet, Jean 1995: Comparative stylistics of French and English. A methodology for translation. Benjamins translation library.

Swales, J. M. 1990: Genre Analysis: English in Academic and Research Settings. Cambridge: Cambridge University Press.

\section{Management's reviews}

Vestas: Arsrapport 2006

FLSmidth \& Co.: Arsrapport 2006

Carlsberg: Årsrapport 2006

Bang \& Olufsen: Arsrapport 2005/06

IC Companys: Årsrapport 2005/06

Gamesa: Informe Anual 2006

Cintra: INFORME ANUAL 2006

Inditex: Memoria 2005

Abertis: informe anual_06

Ferrovial: Informe anual 2006

\section{Corporate Language Guides}

- kindly supplied by:

NEG Micon

Elsam

Grundfos

Danske Bank

Danica Pension 